\title{
SPEECH ACTS ANALYSIS OF DONALD TRUMP'S SPEECH
}

\author{
Nura Siti Mufiah ${ }^{1}$, Muhammad Yazid Nur Rahman² \\ ${ }^{1}$ IKIP SILIWANGI, \\ ${ }^{2}$ IKIP SILIWANGI, \\ 1․nuramufiah@yahoo.com, 22yazidnurrahman95@gmail.com,
}

\begin{abstract}
This research deals with the types of illocutionary acts in Donald Trump's Inaugural Speech. The research concerns with illocutionary act produced by Donald Trumps as a President of American. The aim of this research was to analyze the types of illocutionary speech act which was dominantly used in that speech. This research applied descriptive qualitative method and speech act theory by Yule. There were 63 utterances and the percentage of utterances were Representative $46 \%$, Expressive 11\%, Directive 16\%, Commissive 12,7\%, and Declarative 14,3\%. The result showed that Donald Trump assert to the audience about the nation will be.

It is found that Trump's speech acts in his speech are intended as statement of fact and assertion. Disscussion of hopes implied in Trump's speech acts. As seen on the table above, it can be seen that Trump hoped that his audiences would be persuaded to act
\end{abstract}

Keywords: Speech Act, Speech, Illocutionary act.

\section{INTRODUCTION}

Language is the ways to communicate with other people. Language is a purely human and noninstinctive method of communicating ideas, emotions and desires by means of voluntarily produced symbols" (Hartman and Stork, 1973:124 cited in Kaswan and Suprijadi, 2011:9). Its means a form communication from one person to another where the language is produced by the organs of human voice and released through the mouth producing a series of words which arranged systematically called utterance.

Language can be divided into two categories, direct and indirect. In direct refers to spoken language, much of the meaning is determined by the context. Indirectly refers to written language, its means the representation of a language by means of a writing system. The representation of that direct and indirect phenomenon can be seen from an activity called public speaking.

Speech is a public speaking activity which commonly is in form of formal talk performed by a leader to express his opinion, or give an overview about a thing or event that is important and should be discussed. As a result, many things can be delivered in a speech, like a speech or a victory speech from a leader. In understanding the meaning of certain speech, we need pragmatics competence.

Pragmatics is concerned with the study of meaning as communicated by speaker or writer and interpreted by a listener or reader. According to Yule (1996:3) Pragmatics is the study of speaker meaning. This type of study necessarily involves the interpretation of what kind of people mean in a particular context and how the context influences what is said.

For example :

Table 1. Example of Pragmatics

\begin{tabular}{|l|l|l|}
\hline Sentence : "What time is it ?" & \multicolumn{2}{l|}{ Pragmatics } \\
\hline & Literal & Why are you so late? \\
\hline Meaning & What time is it? & Axplain the reason for being so late. \\
\hline Response & A time (e.g. three o'clock) & Exp
\end{tabular}

From the table 1 above, the utterance "what time is it?" can be imply into two meanings, there are literal meaning and pragmatic meaning. Formulating this knowledge is the essence of what is called the Speech Act Theory.In pragmatics, Speech Acts Theory is the most important phenomenon. 


\section{Mufiah $^{1}$, Rahman $^{2}$ Speech Acts Analysis Of...}

Yule (1996:47) views that "In attempting to express themselves, people do not only produce utterances containing grammatical structures and words, they perform actions via those utterances". Actions performed via utterances are generally called Speech Acts.

According to Yule (1996:48) Speech Acts consists of three related acts, the first is a locutionary act, which is the basic act of utterance, or producing a meaningful linguistic expression. Mostly we don't just produce well-formed utterances with no purpose. We form an utterance with some kind of function in mind. The second dimension is Illocutionary act. That is performed via the communicative force of an utterance. We do not create an utterance with a function without intending it to have an effect. This is the third dimension, the perlocutionary act.

Table 2. Example of Speech Acts

\begin{tabular}{|l|l|l|}
\hline Locution & Illocution & Perlocution \\
\hline $\begin{array}{l}\text { "I've just made some } \\
\text { coffee" }\end{array}$ & $\begin{array}{l}\text { Make a statement, an offer, an } \\
\text { explanation or for some other } \\
\text { communicative purpose. }\end{array}$ & $\begin{array}{l}\text { To get the hearer to drink some } \\
\text { coffee }\end{array}$ \\
\hline
\end{tabular}

In this research, the researcher analyzed the Speech Acts, of the speech from Donald Trump as an American President. Why does the researcher choose this topic? Because of as we know that, Donald Trump's speech is one of the phenomenal president's speech, so the researcher interested to analyze the Donald Trump's speech especially in Speech Acts. Speech Acts is one phenomenon of pragmatics.

Pragmatics is study of meaning as communicated by speaker or writer and interpreted by a listener or reader. According to Yule (1996:3) there are four areas that Pragmatics concerned with:

1). Pragmatics is the study of speaker meaning

Pragmatics is concerned with the study of meaning as communicated by a speaker (or writer) and interpreted by a listener (or reader). It has consequently, more to do with the analysis of what people mean by their utterances than what the words or phrases in those utterances might mean by themselves.

2). Pragmatics is the study of contextual meaning.

This type of study necessarily involves the interpretation of what people mean in a particular context and how the context influences what is said.

3). Pragmatics is the study of how more gets communicated than is said.

This type also explores how listeners can make inferences about what is said in order to arrive at an interpretation of the speaker's intended meaning. This type of study explores how a great deal of what is unsaid is recognized as part of what is communicated.

4). Pragmatics is the study of the expression of relative distance.

How close or distant the listener is speakers determine how much needs to be said.

Pragmatics is viewed as the study of language use in particular communicative contexts or situations of necessity, it would take knowledge of the message being communicated or the speech act being performed; the participants involved; their intention, knowledge of the world and the impact of these on their interactions; what they have taken for granted as part of the context; the deductions they make on the basis of the context; what is implied by what is said or left unsaid; etc. (Leech, 1983, p. 20; Watson \& Hill, 1993, p. 146; Thomas, 1995, p. 7) cited in Dylgjeri (2017:19-20).

\section{Speech Acts Theories}

Speech acts consists of three related acts, the first is a locutionary act, which is the basic act of utterance, or producing a meaningful linguistic expression. Mostly we don't just produce well-formed utterances with no purpose. We form an utterance with some kind of function in mind. The second dimension is Illocutionary act. That is performed via the communicative force of an utterance. We do not create an utterance with a function without intending it to have an effect. This is the third dimension, the perlocutionary act (Yule, 1996:48).

According to Austin (1962) in Dylgjeri (2017:21) Speech Acts divided into three classes, which are locutionary, illocutionary and perlocutionary acts. 1). Locutionary act, which is the basic act of 
utterance, or producing a meaningful linguistic expression. A locutionary act is an act of saying something, that is the act of producing an utterance. 2).Illocutionary act is performed via the communicative force of an utterance. 3).Perlocutionary act is the effect or influence on the feelings, thoughts or actions of listener/hearer unlike locutionary acts. Perlocutionary act could be inspiring, persuading, consoling, promising, encouraging and etc. Of these three dimensions, the most discussed in this research is illocutionary force. The illocutionary force of an utterance is what it "counts as".

From both theories, can be conclude that there are three classes of speech acts. That are Locutionary act, Illocutionary act and Perlocutionary act.

\section{Speech Act Classification}

Yule (1996:53) views that there are five types of general functions performed by speech acts, such as representatives, expressive, directives, commissives, and declaratives.

a. Representatives: are those kinds of speech acts that state what the speaker believes to be the case or not. Statement of fact, assertions, conclusions and descriptions.

In using a representative, the speaker makes words fit the world (of belief).

Example : a. The earth is flat.

b. Chomsky didn't write about peanuts.

c. It was a warm sunny day.

b. Expressive: are those kinds of speech acts that state what the speaker feels. They express psychological state and can be statements of pleasure, pain, likes, dislikes, joy or sorrow. In using an expressive, the speaker makes words fit the world (of feeling).

Example : a. I'm really sorry!

b. Congratulations!

c. Oh, yes, great, mmmm, ssahh!

c. Directives: are those kinds of speech acts that speakers use to get someone else to do something. They express what the speaker wants. They are commands, orders, requests, and suggestions. In using directives, the speaker attempts to make the world fit the words (via the hearer).

Example : a. Gimme a cup of coffee. Make it black.

b. Could you lend me a pen, please?

c. Don't touch that.

d. Commissives: are those kinds of speech acts that speakers use to commit themselves to some future action. They express what the speaker intends. They promise, threats, refusals and pledges. In using a commissive, the speaker undertakes to make the world fit the words (via the speaker).

Example : a. I'll be back.

b.I'm going to get it right next time

c. We will not do that.

e. Declarations: are those kinds of speech acts that change the world via their utterance. The speaker has to have a special institutional role, in specific context, in order to perform a declaration appropriately. In using a declaration, the speaker changes the world via words.

Example : a. Priest: I now pronounce you husband and wife.

b. Referee : You're out!

According to Searle (1979) cited in Altikriti (2011:3), as an improvement of the classification of the speech acts proposed by Austin, classifies speech acts into five categories:

1. Representative: these speech acts carry the values 'true; or ' falls', i.e., they commit the speaker to the truth of the expressed proposition such as asserting, reporting, instructing, concluding, etc.

2. Directives: the speaker's role is to get (to direct) the hearer to do something (or towards some goal)

3. Commissives: Seale calls it "unexceptionable", i.e. the obligation created in the word by commissives is created in the speaker not in the hearer. So they commit the speaker to some future action, such as offering, threatening, promising, etc. 
4. Expressives: these express an inner state of the speaker. They tend to be intrinsically polite as in greeting, thanking, congratulating, etc.; and the reverse is true as in blaming and accusing.

5. Declarations: these show the correspondence between the prepositional content and reality and as Searle calls "a very special category of speech acts", such as resigning, dismissing, christening, naming, sentencing, etc.

\section{METHOD}

The research design in this research is qualitative research design with content analysis research. According to Kaswan \& Suprijadi (2016:15) Qualitative research design is a research design that places primary importance on studying small samples of purposely chosen individuals, not attempting to control contextual factors, but rather seeking, through a variety of methods, to understand things from the informants' points of view, and creating a rich and in-depth picture of the phenomena under investigation.

The technique used in this research is collecting the secondary data. The research procedure included: finding data, classification data, and analyzing the result of data.

The data is analyzed by collecting, selecting, and classifying the suitable utteranceswith the method and relevant concept especially Yule's theory on illocutionary acts. In this research, the process of collecting data is done through the following steps:

1. Searching the video of speech and its script

2. Reading the script

3. Choosing the illocutionary acts on the script

4. Grouping the utterances in relation to the types of illocutionary acts

5. Analyzing the data

6. Writing the report of the research.

\section{RESULTS AND DISCUSSION}

\section{Results}

The data collection of this research was taken from the victory speech of Donald Trump in The Inaugural Address on Friday, January 20, 2017 Washington D.C.

http://www.whitehouse.gov/briefings-statements/the-inaugural-address/

Table. 3 The list of illocutionary of Representative

\begin{tabular}{|c|c|c|}
\hline No & Locutionary / Statement & Type of Illocutionary \\
\hline 1. & $\begin{array}{l}\text { Washington flourished - but the people did not share in its } \\
\text { wealth. }{ }^{10}\end{array}$ & $\begin{array}{l}\text { Representative (Statement of } \\
\text { fact) }\end{array}$ \\
\hline 2. & $\begin{array}{l}\text { Politicians prospered - but the jobs left, and the factories } \\
\text { closed. }{ }^{11}\end{array}$ & $\begin{array}{l}\text { Representative (Statement of } \\
\text { fact) }\end{array}$ \\
\hline 3. & $\begin{array}{l}\text { The establishment protected itself, but not the citizens of } \\
\text { our country. }{ }^{12}\end{array}$ & $\begin{array}{l}\text { Representative (Statement of } \\
\text { fact) }\end{array}$ \\
\hline 4. & $\begin{array}{l}\text { What truly matters is not which party controls our } \\
\text { government, but whether our government is controlled by } \\
\text { the people. }{ }^{18}\end{array}$ & Representative (Assertion) \\
\hline 5. & Everyone is listening to you now. ${ }^{21}$ & Representative (Assertion) \\
\hline 6. & $\begin{array}{l}\text { You came by the tens of millions to become part of a } \\
\text { historic movement the likes of which the world has never } \\
\text { seen before. }{ }^{22}\end{array}$ & Representative (Assertion) \\
\hline
\end{tabular}




\begin{tabular}{|c|c|c|}
\hline 7. & $\begin{array}{l}\text { At the center of this movement is a crucial conviction: that } \\
\text { a nation exists to serve its citizens. }{ }^{23}\end{array}$ & Representative (Assertion) \\
\hline 8. & $\begin{array}{l}\text { These are the just and reasonable demands of a righteous } \\
\text { public. }{ }^{25}\end{array}$ & Representative (Assertion) \\
\hline 9. & $\begin{array}{l}\text { But for too many of our citizens, a different reality exists: } \\
\text { Mothers and children trapped in poverty in our inner } \\
\text { cities; rusted-out factories scattered like tombstones across } \\
\text { the landscape of our nation; an education system, flush } \\
\text { with cash, but which leaves our young and beautiful } \\
\text { students deprived of knowledge; and the crime and gangs } \\
\text { and drugs that have stolen too many lives and robbed our } \\
\text { country of so much unrealized potential. }{ }^{26}\end{array}$ & Representative (Description) \\
\hline 10. & $\begin{array}{l}\text { We are one nation - and their pain is our pain, their } \\
\text { dreams are our dreams; and their success will be our } \\
\text { success, we share one heart, one home, and one glorious } \\
\text { destiny. }{ }^{28}\end{array}$ & Representative (Assertion) \\
\hline 11. & $\begin{array}{l}\text { For many decades, we've enriched foreign industry at the } \\
\text { expense of American industry. }{ }^{30}\end{array}$ & Representative (State of fact) \\
\hline 12. & $\begin{array}{l}\text { Subsidized the armies of other countries while allowing for } \\
\text { the very sad depletion of our military. }\end{array}$ & Representative (State of fact) \\
\hline 13. & $\begin{array}{l}\text { We've defended other nation's borders while refusing to } \\
\text { defend our own; } 32\end{array}$ & Representative (State of fact) \\
\hline 14. & $\begin{array}{l}\text { And spent trillions of dollars overseas while America's } \\
\text { infrastructure has fallen into disrepair and decay. }{ }^{33}\end{array}$ & Representative (State of fact) \\
\hline 15. & $\begin{array}{l}\text { We will seek friendship and goodwill with the nations of } \\
\text { the world - but we do so with the understanding that it is } \\
\text { the right of all nations to put their own interests first. }{ }^{50}\end{array}$ & Representative (Assertion) \\
\hline 16. & $\begin{array}{l}\text { We do not seek to impose our way of life on anyone, but } \\
\text { rather to let it shine as an example for everyone to } \\
\text { follow. }\end{array}$ & Representative (Assertion) \\
\hline 17. & $\begin{array}{l}\text { At the bedrock of our politics will be a total allegiance to } \\
\text { the United States of America, and through our loyalty to } \\
\text { our country, we will rediscover our loyalty to each other. }{ }^{53}\end{array}$ & Representative (Assertion) \\
\hline 18. & $\begin{array}{l}\text { When you open your heart to patriotism, there is no room } \\
\text { for prejudice. }{ }^{54}\end{array}$ & Representative (Assertion) \\
\hline 19. & $\begin{array}{l}\text { The Bible tells us, "how good and pleasant it is when } \\
\text { God's people live together in unity." } 55\end{array}$ & Representative (State of fact) \\
\hline 20. & $\begin{array}{l}\text { There should be no fear - we are protected, and we will } \\
\text { always be protected. }{ }^{58}\end{array}$ & Representative (Assertion) \\
\hline 21. & $\begin{array}{l}\text { We will be protected by the great men and women of our } \\
\text { military and law enforcement and, most importantly, we } \\
\text { are protected by God. }{ }^{59}\end{array}$ & Representative (Assertion) \\
\hline 22. & Finally, we must think big and dream even bigger. ${ }^{60}$ & Representative (Conclusion) \\
\hline 23. & $\begin{array}{l}\text { In America, we understand that a nation is only living as } \\
\text { long as it is striving. }{ }^{61}\end{array}$ & Representative (Assertion) \\
\hline 24. & We will not fail. $^{75}$ & Representative (Assertion) \\
\hline 25. & $\begin{array}{l}\text { It is time to remember that old wisdom our soldiers will } \\
\text { never forget: that whether we are black or brown or white, } \\
\text { we all bleed the same red blood of patriots, we all enjoy } \\
\text { the same glorious freedoms, and we all salute the same } \\
\text { great American Flag. }{ }^{70}\end{array}$ & Representative (Description) \\
\hline 26. & $\begin{array}{l}\text { And whether a child is born in the urban sprawl of Detroit } \\
\text { or the windswept plains of Nebraska, they look up at the }\end{array}$ & Representative (Description) \\
\hline
\end{tabular}


same night sky, they fill their heart with the same dreams, and they are infused with the breath of life by the same almighty Creator. ${ }^{71}$

27. So to all Americans, in every city near and far, small and large, from mountain to mountain, and from ocean to ocean, hear these words: ${ }^{72}$

28. You will never be ignored again. ${ }^{73}$

29. Your voice, your hopes, and your dreams, will define our American destiny, and your courage and goodness and love will forever guide us along the way. ${ }^{74}$

Representative (Conclusion)

Table. 4 The list of illocutionary of Expressive

\begin{tabular}{|c|c|c|}
\hline No & Locutionary / Statement & Type of Illocutionary \\
\hline 1. & $\begin{array}{l}\text { Every four years, we gather on these steps to carry out the } \\
\text { orderly and peaceful transfer of power, and we are } \\
\text { grateful to President Obama and First Lady Michelle } \\
\text { Obama for their gracious aid throughout this transition. }{ }^{5}\end{array}$ & Expressive (Joy) \\
\hline 2. & They have been magnificent. ${ }^{6}$ & Expressive (like) \\
\hline 3. & $\begin{array}{l}\text { Their victories have not been your victories; their triumphs } \\
\text { have not been your triumphs; and while they celebrated in } \\
\text { our nation's Capital, there was little to celebrate for } \\
\text { struggling families all across our land. }{ }^{13}\end{array}$ & Expressive (pain) \\
\hline 4. & $\begin{array}{l}\text { We've made other countries rich while the wealth, } \\
\text { strength, and confidence of our country has disappeared } \\
\text { over the horizon. }\end{array}$ & Expressive (sorrow) \\
\hline 5. & $\begin{array}{l}\text { One by one, the factories shuttered and left our shores, } \\
\text { with not even a thought about the millions upon millions of } \\
\text { American workers left behind. }{ }^{35}\end{array}$ & Expressive (sorrow) \\
\hline 6. & $\begin{array}{l}\text { The wealth of our middle class has been ripped from their } \\
\text { homes and then redistributed across the entire world. }{ }^{36}\end{array}$ & Expressive (sorrow) \\
\hline 7. & $\begin{array}{l}\text { A new national pride will stir our souls, lift our sights, and } \\
\text { heal our divisions. }{ }^{69}\end{array}$ & Expressive (like) \\
\hline
\end{tabular}

Table. 5 The list of illocutionary of Directive

\begin{tabular}{|l|l|l|}
\hline No & Locutionary / Statement & Type of Illocutionary \\
\hline 1. & $\begin{array}{l}\text { Together, we will determine the course of America and the } \\
\text { world for years to come. }^{3}\end{array}$ & Directive (orders) \\
\hline 2. & $\begin{array}{l}\text { Americans want great schools for their children, safe } \\
\text { neighborhoods for their families, and good jobs for } \\
\text { themselves. }^{24}\end{array}$ & Directive (suggestion) \\
\hline 3. & $\begin{array}{l}\text { This American carnage stops right here and stops right } \\
\text { now. }{ }^{27}\end{array}$ & Directive (command) \\
\hline 4. & $\begin{array}{l}\text { But that is the past, and now we are looking only to the } \\
\text { future. }{ }^{37}\end{array}$ & Directive (orders) \\
\hline 5. & $\begin{array}{l}\text { We must protect our borders from the ravages of other } \\
\text { countries making our products, stealing our companies, } \\
\text { and destroying our jobs. }{ }^{42}\end{array}$ & Directive (command) \\
\hline 6. & $\begin{array}{l}\text { We will reinforce old alliances and form new ones - and } \\
\text { unite the civilized world against Radical Islamic } \\
\text { Terrorism, which we will eradicate completely from the }\end{array}$ & Directive (orders) \\
\hline
\end{tabular}




\begin{tabular}{|l|l|l|}
\hline & face of the Earth. & \\
\hline 7. & $\begin{array}{l}\text { We must speak our minds openly, debate our } \\
\text { disagreements honestly, but always pursue solidarity. }\end{array}$ & Directive (suggestion) \\
\hline 8. & Now arrives the hour of action..$^{64}$ & Directive (command) \\
\hline 9. & Do not let anyone tell you it cannot be done. ${ }^{65}$ & Directive (command) \\
\hline 10. & Together, We Will Make America Strong Again. ${ }^{75}$ & Directive (orders) \\
\hline
\end{tabular}

Table. 6 The list of illocutionary of Commissive

\begin{tabular}{|l|l|l|}
\hline No & Locutionary / Statement & Type of Illocutionary \\
\hline 1. & $\begin{array}{l}\text { We will face challenges, we will confront hardships, but we } \\
\text { will get the job done. }\end{array}$ & Commissive (pledges) \\
\hline 2. & $\begin{array}{l}\text { Every decision on trade, on taxes, on immigration, on } \\
\text { foreign affairs, will be made to benefit American workers } \\
\text { and American families. }{ }^{41}\end{array}$ & Commissive (pledges) \\
\hline 3. & $\begin{array}{l}\text { I will fight for you with every breath in my body - and I } \\
\text { will never, ever let you down. }{ }^{44}\end{array}$ & Commissive (promise) \\
\hline 4. & $\begin{array}{l}\text { America will start winning again, winning like never } \\
\text { before. }{ }^{45}\end{array}$ & Commissive (pledges) \\
\hline 5. & $\begin{array}{l}\text { We will bring back our jobs, we will bring back our } \\
\text { borders, we will bring back our wealth, and we will bring } \\
\text { back our dreams. }{ }^{46}\end{array}$ & Commissive (pledges) \\
\hline 6. & $\begin{array}{l}\text { We will build new roads, and highways, and bridges, and } \\
\text { airports, and tunnels, and railways all across our } \\
\text { wonderful nation. }{ }^{47}\end{array}$ & Commissive (pledges) \\
\hline 7. & $\begin{array}{l}\text { We will get our people off of welfare and back to work - } \\
\text { rebuilding our country with American hands and American } \\
\text { labor. }{ }^{48}\end{array}$ & Commissive (pledges) \\
\hline 8. & Our country will thrive and prosper again. ${ }^{67}$ & Commissive (pledges) \\
\hline
\end{tabular}

Table. 7 The list of illocutionary of Declarative

\begin{tabular}{|c|c|c|}
\hline No & Locutionary / Statement & Type of Illocutionary \\
\hline 1. & $\begin{array}{l}\text { Because today we are not merely transferring power from } \\
\text { one Administration to another, or from one party to } \\
\text { another-but we are transferring power from Washington, } \\
\text { D.C. and giving it back to you, the American People. }{ }^{8}\end{array}$ & Declarative \\
\hline 2. & $\begin{array}{l}\text { That all changes - starting right here, and right now, } \\
\text { because this moment is your moment: it belongs to you. }{ }^{14}\end{array}$ & Declarative \\
\hline 3. & This is your day, this is your celebration. ${ }^{16}$ & Declarative \\
\hline 4. & And this, the United States of America, is your country. ${ }^{17}$ & Declarative \\
\hline 5. & $\begin{array}{l}\text { January 20th } 2017, \text { will be remembered as the day the } \\
\text { people became the rulers of this nation again. } 19\end{array}$ & Declarative \\
\hline 6. & $\begin{array}{l}\text { The oath of office I take today is an oath of allegiance to } \\
\text { all Americans. } .^{29}\end{array}$ & Declarative \\
\hline 7. & $\begin{array}{l}\text { We assembled here today are issuing a new decree to be } \\
\text { heard in every city, in every foreign capital, and in every } \\
\text { hall of power. }{ }^{38}\end{array}$ & Declarative \\
\hline 8. & $\begin{array}{l}\text { From this day forward, a new vision will govern our } \\
\text { land. }{ }^{39}\end{array}$ & Declarative \\
\hline 9. & From this moment on, it's going to be America First. ${ }^{40}$ & Declarative \\
\hline
\end{tabular}




\section{Discussion}

Based on the findings, five types of illocutionary acts expressed by Donald Trump found in his speech. The data is summarized in the table below:

Table. 9 Percentage Illocutionary Acts in Donald Trump's Speech

\begin{tabular}{|l|l|l|l|}
\hline No. & $\begin{array}{l}\text { Types of Illocutionary } \\
\text { Acts }\end{array}$ & Sentences & Total \\
\hline 1. & Representative & $\begin{array}{l}\text { Statement of fact (8), Assertion (16), Description (3), } \\
\text { Conclusion (2) }\end{array}$ & 29 \\
\hline 2. & Expressive & Like (2), Joy (1), Sorrow (3), pain (1) & 7 \\
\hline 3. & Directive & Command (4), Ordering (4), Suggesting (2) & 10 \\
\hline 4. & Commissive & Promise (1), Pledges (7) & 8 \\
\hline 5. & Declarative & Declaration (9) & 9 \\
\hline
\end{tabular}

From that data, we conclude the percentage of illocutionary that uses are Representative $46 \%$, Expressive 11\%, Directive 16\%, Commissive 12,7\%, and Declarative 14,3\%.

After the researcher analyzed and classified the data there were found the number of speech acts. In the result showed that most of speech act illocutionary act occur in Donald trump utterances is Representative.

Through the analysis of the speech, it is the representative speech act that is highly used with (29) instances and represents $46 \%$ out of the total number of utterances in the whole text (63).

In Donald Trumps's speech, he assert to the audience about the nation will be.

It is found that Trump's speech acts in his speech are intended as statement of fact and assertion. Disscussion of hopes implied in Trump's speech acts. As seen on the table above, it can be seen that Trump hoped that his audiences would be persuaded to act.

\section{CONCLUSION}

According to the results in the previous point, the illocutionary act of representative (46\%) is often used by Donald Trump in his utterances. Representative potentially represents the factual, informative, and supportive nature of the speaker. Representative is the act that state what the speaker believes to be the case or not.

The second most dominant act is directive (16\%), which represents power and the dominance of the speaker. Directive is the act that the speaker uses to get someone else to do something. Directive act does not obligate the hearer to do something the speaker wants.Then, the illocutionary act of expressive (11\%) is the least used by Donald Trump in his utterances. This act states what the speaker feels, that can be psychological states or statements of pleasure, pain, likes, dislikes, joy, or sorrow.

From this result we can conclude that most of the utterance Donald Trump's speech used representative speech acts.

\section{REFERENCES}

Altikriti, SF. 2011. Speech Act Analysis to Short Stories. Journal of Language Teaching and Research, Vol. 2, No. 6, pp. 1374-1384. ACADEMY PUBLISHER Manufactured in Finland.

Dylgjerii ,ArditaP. Analysis Of Speech Acts In Political Speeches “Aleksander Xhuvani” University, Elbasan, Albania

Kaswan \& Dasep Suprijadi. (2011). Language in Society. Bandung: Putra Praktisi.

Kaswan \& Dasep Suprijadi. (2016). Research in English Education. Bandung: Putra Praktisi.

Yule, George.(1996). Pragmatics.Oxford University Press 1996. 